\title{
Strategic Directions of Strengthening Competition on Higher Education Market of Georgia
}

\author{
Tabatadze Lasha, PhD student \\ Grigol Robakidze University/Georgia
}

doi: 10.19044/esj.2016.v12n4p120 URL:http://dx.doi.org/10.19044/esj.2016.v12n4p120

\begin{abstract}
In the present article the results of wide scale research for studying and analyzing the competition issues of Higher Education Market of Georgia, which is made by the author independently in 2015 under the framework of dissertation survey are reviewed. It contents detail description of activities needed for collecting and analyzing information to develop a research paper of Georgian Higher education market, which includes three level of higher educatioin institutions (University, Teaching University and College). The article presents the research report and its comparative and critical analyze taking under consideration the experience of Baltic and European countries.
\end{abstract}

Keywords: HE market of Georgia, competition issues of HE

\section{Introduction}

It is worth mentioning that nowadays the world globalization processes reach the peak and it has a great influence on international competition. Accordingly, the impact is spreading not only on business companies, but also on HE market. The abovementioned changes prioritize discussing HEIs from other approaches. HEIs present not only education supplier local organizations, but also they are business organizations functioning in more and more growing competitive environment in which they are competing as all other types of companies for strengthening the positions in the local as well as in the international markets.

In fact, globalization defined the new standards of competition on HE market, in which the main strategic directions are internationalization of Higher Education, funding models of Higher Education, close connection between HEIs and employers. 
I.

According to the National Statistics Office of Georgia 72 HEIs are registered in Georgia today, including 52 private and 20 public one, where about 124000 students are studying. (See Chart 1). [11].

Chart.1. Number of Higher Education Institutions in Georgia

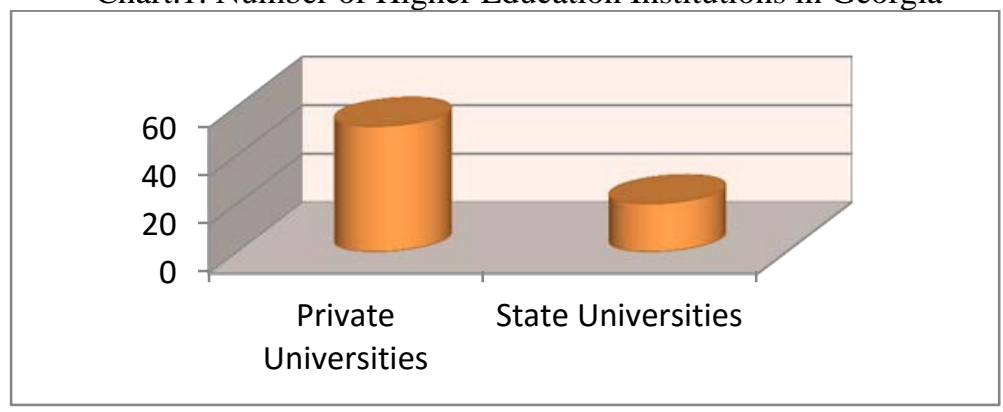

At first glance HE market seems competitive enough. It is paradox but existing quantity of HEIs may be considered as a prerequisite of unfair competition in the country with $3,7 \mathrm{mln}$. population because of four qualification of graduates and hence the lack of professionals at labor market. [11].

Within the limits of research the study and critical analysis of Georgian and foreign authors' works dedicated to the problems of education market, of various scientific -practical conferences, international forums materials, research reports of international organizations, legal standards of local and international significance including declarations and agreements with regard for the experience of Baltic and European countries allowed us to determine main priorities of competitiveness of higher educational service market such as: internationalization of higher education, models of funding higher education, support and development of close relationship between higher educational institutions and employers.

At present, a great attention is focused on internationalization as on one of the main determinative components of supporting and improving higher education. For illustration we present international associations, wellknown all over the world supporting higher education and internalization:

European university Association (EUA) founded in 2001, consolidated European leading universities and is well-known in the world. it is especially well known by Lisbon Declaration, which has been jointly worked out by European leading universities, the members of the association and is considered as an active motivator of Bologna process;

- International Association of Universities (IAU) founded in 1950 on the basis of UNESCO, is the world organization of higher 
educational institutions which unites the world leading universities by means of educational and teaching strategy;

- International Association of University Presidents (IAUP) founded in 60-sof last century is the world association of high ranking officials of universities. These international association have common aims and purposes among which can be emphasized three main priorities:

1. Deeping international mission of universities on a world scale as a perquisite of sustainable development of the world

2. Formation of global vision of higher education development;

3. Sharing know-how and educational scientific collaboration between partner universities.

Moreover, IAUP has higher consultation rights to UNO and formal consultation rights to UNESCO. It must be noticed that the absolute majority of Georgian higher educational institutions has neither full member status nor member status, nor member candidate status; it is pity, because the worlds experience would be of great support for our country in the conditions of existing global challenges.

Besides ranking lists of world -fame higher educational institutions have been found within the limits of research where are considered internationalization components:

- Times Higher Educational Supplement (THES);

- Academic rank of World Universities (ARWU);

- Rank of World Universities of Quacquarelli Symonds (QS);

- Rank of Webometrics (WM).

It must be noted that unfortunately to day Georgian Higher educational institutions do not appear any where except WM ranking list. The situation is radically different in the universities of European leading countries (France, Germany, Great Britain) and in Baltic Sea countries as well (Lithuania, Latvia, Estonia). The above-mentioned countries take an active part in the internationalization processes. Moreover, they are the member countries of international associations and they also appear in the ranking lists of world-fame higher educational institutions. [12].

The carried out research shows that higher educational service market of Georgia is steel facing a great number of unsolved problems, in particular $60 \%$ of respondents (HEI) announce that they have joint training programs, but $40 \%$ have not. (See Chart 2). [1]. 
Chart 2. Statistics of Joint programs.

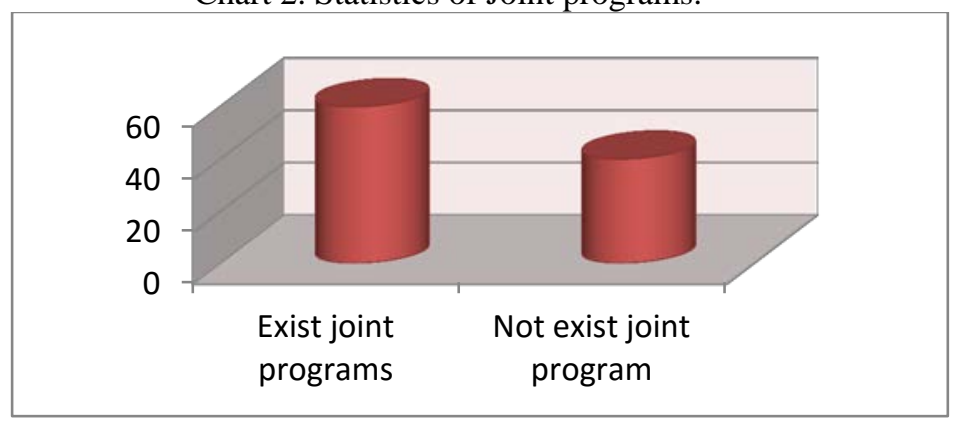

$100 \%$ of respondents noted that international accreditation is very important for universities as prerequisite for increasing their competitiveness. Unfortunately, it should be noted that in Georgia the universities have no international accreditation at higher educational service market. The situation with respect to internationalization degree of personnel is deplorable top. $100 \%$ of respondents answer that their academic personnel is staffed entirely by local specialists and absolute majority is engaged in training processes.

It should be noted that analogous index of European and Baltic Sea countries as well (Lithuania, Latvia, Estonia) is quite different. In the abovementioned countries absolute majority of universities has got international accreditation with equal percentage ratio, towards local programs, realizes joint educational programs at three levels of training and the main thing is that their academic personnel speaks perfectly foreign languages and their academic activity is not only giving lectures and seminars, their scientific activity is realized in various leading universities af the world and published in high rank international reviewed journals with citation high index. [13].

It would be interesting to know one more index of internationalization in higher educational institutions: the ratio between local and foreign students. According to official data of Georgian Departement of Statistics, the number of students sent abroad from Georgia is $10 \%$, in comparison with foreign students in Georgia. (see.Chart 3.) [11].

Number of Students studying Abroad and Foreign Students, 2014-2015 school year, persons

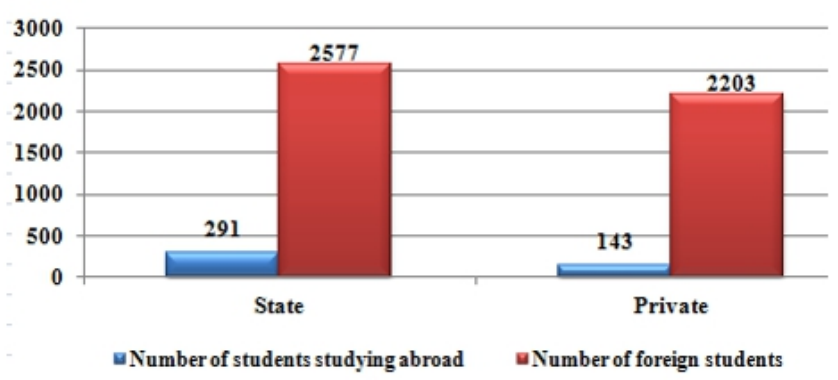


The share of foreign students in sum total of local students does not exceed 1.9-2.0\%, (see.Chart 4), (see.Chart 5). [11].
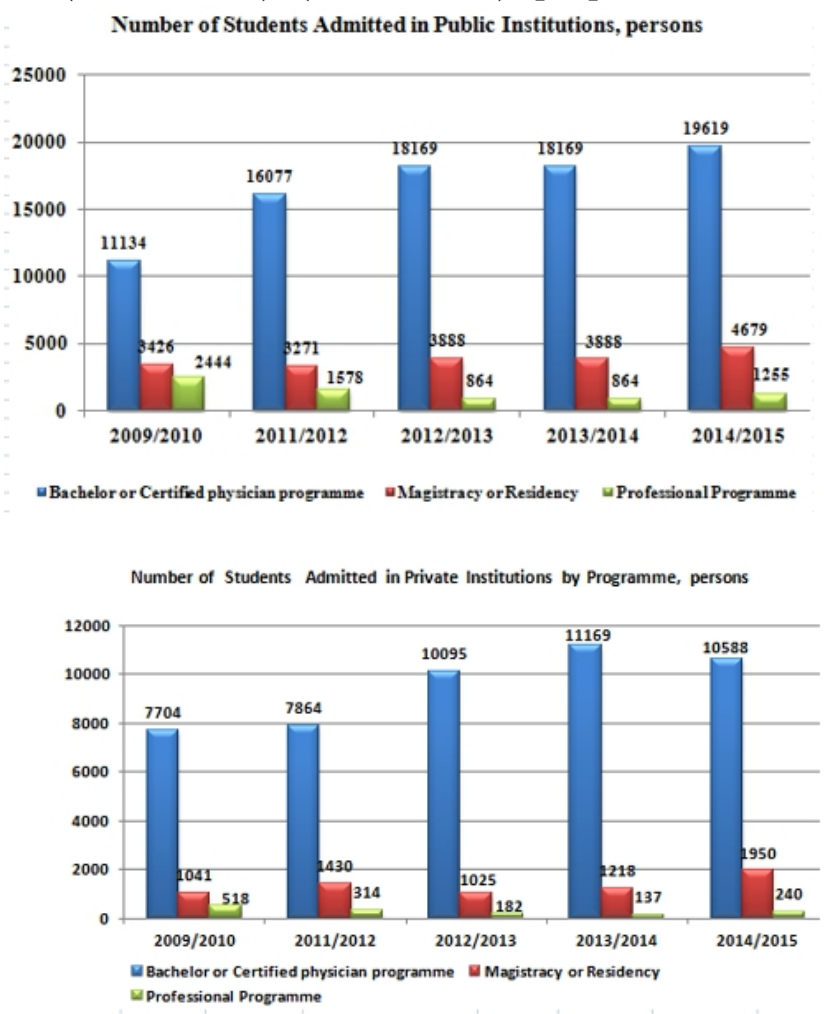

The first case may be explained economically, the study and living in Georgia is more advantageous (cheap). The second case statistics shows evidently the low level of internationalization in Georgia.

For 2014-2015 studying year this indicator in Federal Republic of Germany was 17\%, in Republic of Poland 12\%, in Republic of Lithuania 3\% and in Estonia 2.2\%. Besides, 20-25\% of students in Baltic countries have opportunities to participate in International Exchange Programs through state support. Special support is provided for students, who are on the third level of their education and $10 \%$ of PHD students receive funds for education. $[14,15,16,17,18]$.

Distribution of foreign students by countries is very interesting. Particularly, if majority of foreign students in Georgia come from developing or third world countries, in Baltic region students come from developed countries, such as Finland, Scandinavian countries, western European countries and china. This again confirms high level and quality of internationalization in mentioned countries.

Student participation indicator in Erasmus higher education programs is also interesting. Lithuania, Latvia and Estonia take one of leading places in 
Eastern Europe and are absolute leaders in post-Soviet space. They have impressive positions in the international scholarship projects.

Analysis of research financial bloc is also very interesting. Here focus is made on financing of higher education and on state support model of education.

Absolute majority of respondents (90\%) noted that existing scholarship system and practice of national examinations are not effective. Respondents think that scholarship should necessarily include seconday professional education, master and doctoral studies. Absolute minority of respondents (10\%) deem that financing through state scholarship system is acceptable. (see Chart 6). [1].

Chart 6. Financing of higher education and state support model of education in Georgia.

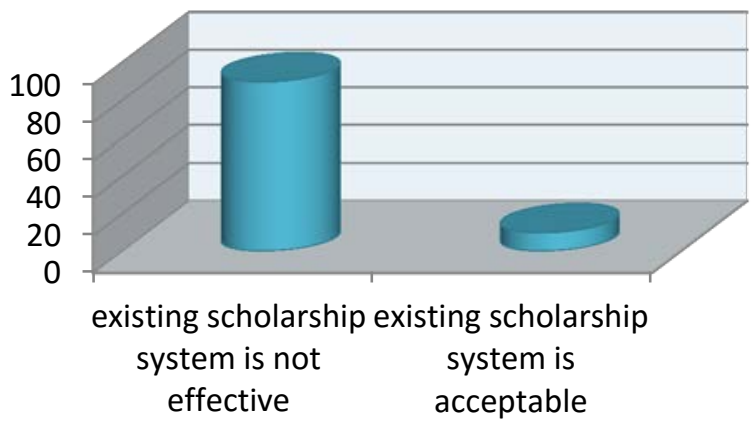

At the same time, as $100 \%$ of respondents have answered, current education fee - $2250 \mathrm{Gel}$, only partially responds to the market price of studying and it is not real market value. According to educational infrastructure, material-technical base and modern methods of teaching, education fee should be higher.

Despite declaration of higher education, scientific-research activities as national priority, allocated funds in these spheres are not enough to provide their long-term, quality development and to create competitive product on the regional and international level. Existing state funding mechanism of higher education and research create instable environment and unfavorable conditions for higher educational institutions.

According to the data of National Statistics Office of Georgia 2015, expenditures on education with respect to GDP are $2.7 \%$. Only third of this amount is spent on higher education, which is approximately 0,9\%. [11].

The same indicator in Baltic countries, where GDP is 5 times higher comparing with Georgia, fluctuates between 2-3\%, which is solid number indeed. 20,21].

According to existing reality, for more optimization of financial resources it is reasonable to increase limits on scholarship, which can bring 
double-sided effect. It will enable us to increase quantity and quality of funding. It is also desirable to determine limit, under which tuition fee should not go, because, in many cases, price cannot fully provide and satisfy functioning aims of higher education institutions and entail dumping characteristics, which hamper creation of competitive environment in the market. Considering European experience, where practice of national examinations practically does not exist, to improve higher education market competitiveness, it is reasonable to allocate bloc-grants for higher institutions from state budget. Amount of these grants will be counted according to the formula.

Formula may include following components:

- Quality of Academic Programs and Teaching;

- Quality of Internalization;

- Indicator of Relations with Private Sector;

- University Positions in the Prominent Ranking Lists.

\section{Conclusion}

It should be noted that we have important improvement in the field of higher education reforms according to the European standards from 2005. Although, relying on the research results, there are wide range of problems, of course. There appeared problems referring to come the Bologna process into force. Although universities meet demands, introduce new mechanisms of teaching and administrating, but it seems that procedures are carrying out by only one reason, because it is crucial for achieving institutional accreditation.

At this stage, internalization degree is low (especially for academic staff). It would be better to improve detail mechanisms of creating joint programs and awarding by joint acadamic degree as well as the procedures for recogntions of studying periods.

The internationalization process is profitable for institutionalization growth of a university, for improving the quality of researching and studying, for attracting more financial resources. In the process of interntionalisation the most crucial role has managing, coordinating and deciding the issue such as developing strategic plan of internationalisation.

The strategy will be directed to institutionalization of internationalization, which means introducing systems and processes that supports and develops infrustructure, exchange programs, which attracts foreign students, joint researches and so on.

The existing funding model which does not totally covers the three level of education should be reviewed, while the state grant amount is irrelevant to the existing free market price. The rule of defining studying price could not provide high quality oriented functioning. State grant 
awarding mechanisms contains some risks, too. National Examination model faces against the autonomy principle of a university, as it is not allowed to choose students itself independently but the process is totally outside of the university management.

Also, financing the only professions, defined by the government without developing any general rule and without taking under consideration possible results is risky, too. The existing model of financing by voucher system is restricting the autonomy of a university and is a breaking factor of a free competition in HE market, too.

\section{References:}

Prof.Dr. Kikutadze Vasili-(superwiser of research), Tabatadze Lasha(Coordinator of research), Georgian HEI market research, Tbilisi, Georgia, 2015;

Miller Leon, Matveeva Elena, Nekrasova Natalia, The Internationalization of Estonian Higher Education:How the Estonian Cultural Context Impacts the Experience of Foreign Students, Talin Univesity of Technology, 2012;

Lorange Peter, Thought Leadership Meets Business. „How Business Schools Can Become More Succesful” Cambridge University Press, 2009;

Karveliene Regina, The Bologna Process and the Features of Implementation of the Internationalization of Higher Education in Lithuania, Siauliai University, 2013;

Bunning Frank, The Transformation of Vocational Education and Training (VET) in the Baltic States - Survey of Reforms and Developments (Technical and Vocational Education-Training: Issues, Concerns and Prospects) [1 ed.] 2010;

Bileviciute.E. Zaleniene.I.,,Higher Education Reform in Lithuania with Emphasis on Lithuanian Educational Strategy”,2013;

Prof.Dr.KreituseI, Prof.Dr.Gurbo S, (Rīga Stradiņ̌̌ University Latvia), „Higher Education in Latvia on the Threshold of Reforms, 2012;

Prof.Dr.Leisyte, L.\& Dobbins, M.,,Analyzing the transformation of higher education governance in Bulgaria and Lithuania”,2011;

Prof.Dr. Jezierska, J. M „Quality assurance policies in the European Higher Education Area: A comparative case study" Las Vegas: University of Nevada Las Vegas, 2009;

Prof.Dr. De Boer, H., Enders, J., \& Schimank, U. „,On the Way Towards New Public Management? The Governance of Univerity Systems in Englang, the Netherlands, Austria, and Germany”, 2007;

Erasmus in the Baltic Countries, Lifelong Learning Programme 2008-2013, Statistical Overview, 2013;

http://www.geostat.ge/

http://www.tempus-us.com/us/index.php; 
http://www.scholars4dev.com/2979/erasmus-mundus-scholarships-fordeveloping-countries;/

http://www.eua.be/Home.aspx;

http://iau-aiu.net/;

http://iaup.org/;

http://talk.collegeconfidential.com/graduate-school/999030-thes-worlduniversity-ranking-2010.html;

http://www.usnews.com/education/bestglobaluniversities/search?region=eur ope\&subjece http://ec.europa.eu/eurostat/data/database http://www.shanghairanking.com/World-University-Rankings/VilniusUniversity.html

http://www.dw.com/en/germany-says-willkommen-to-foreign-students/a17790362

http://www.bachelorsportal.eu/countries/20/poland.html?gclid=CIn6tOvQ4sc CFUZAGwodo_oCPQ https://www.hm.ee/en/news/foreign-students-value-studying-estonia-highly http://www.bachelorsportal.eu/countries/17/lithuania.html https://student.slu.se/en/studies/studyabroad/exchangestudies/wherecanistudy /nordicregion-baltic-states/

http://www.pmcg-i.com/publications/newsletter/item/850-issue-46education-and-science-sector-2014 http://www.oecd-ilibrary.org/education/education-at-a-glance2014/expenditure-on-educational-institutions-as-a-percentage-of-gdp-for-alllevels-of-education-2000-2008-and-2011_eag-2014-graph118-en; http://www.hlcommission.org http://www.unl.edu http://www.ku.edu http://www.wisc.edu http://www.mindtools.com http://www.managementhelp.org http://www.cihe.neasc.org 